Marcin Chorązki

[Kraków ]

\title{
Świadek, protokół przesłuchania świadka \\ oraz relacje jako źródło do badania dziejów historii najnowszej. \\ Podobieństwa i różnice w pracy prokuratora IPN i historyka
}

Spotkanie naukowca z człowiekiem, który był świadkiem wydarzeń historycznych ma zawsze wyjątkowe znaczenie dla słuchacza. Każdy, kto ma możliwość wysłuchania ciekawej opowieści o przeszłości nawiązuje dialog z relacjonującym, starając się dowiedzieć więcej i zrozumieć kontekst przekazu, jak i opisywane zjawiska. W ten sposób traktują nagranie wywiadu nie tylko historycy, lecz także socjologowie, antropolodzy czy też etnologowie. Szczególnym rodzajem wywiadu jest przesłuchanie świadka przez prokuratorów Instytutu Pamięci Narodowej Komisji Ścigania Zbrodni przeciwko Narodowi Polskiemu (IPN). Ten rodzaj spotkania świadka z osobą zainteresowaną, a zarazem urzędnikiem państwowym, posiada dodatkowy charakter, wynikający z natury sytuacji prawno-formalnej. Dlatego moim celem w niniejszym artykule jest wskazanie różnic i podobieństw w obydwu rodzajach źródeł historycznych, ze szczególnym uwzględnieniem nie tylko ich natury, ale też okoliczności ich powstawania. Wykorzystam w tym celu doświadczenie, które nabyłem podczas wieloletniej pracy w Instytucie Pamięci Narodowej Oddziałowej Komisji Ścigania Zbrodni przeciwko Narodowi Polskiemu w Krakowie. Spośród analizowanych przypadków wybrałem świadka historii, który zeznawał przed prokuratorami Oddziałowej Komisji w Krakowie, 
a także udzielił relacji biograficznej krakowskim historykom. Artykuł ma charakter rekonesansu poznawczego, ma on stanowić głos w dyskusji nad rolą świadka we współczesnych badaniach historycznych. Chciałbym również sprowokować refleksję na temat roli świadka w pracy historyka i prokuratora IPN. Nie podejmuję się analizy roli świadka w śledztwach UBP, ponieważ to zagadnienie zostało już opracowane ${ }^{1}$. W metodologii historii oba rodzaje źródeł mają cechy wspólne - są wywołane i ich efektem jest zapis (na piśmie, a także audio lub wideo). Wyłączam z niniejszej analizy wszelkie pisemne materiały wspomnieniowe, pamiętniki, a także dzienniki, koncentrując się na dialogu dwóch osób - świadka i prokuratora lub historyka.

Wśród historyków często spotykaną formą zdobywania wiedzy na temat interesujących ich wydarzeń i zjawisk jest przeprowadzanie wywiadów ${ }^{2}$. Ta metoda określana przez środowisko naukowe jako historia mówiona, opiera się na metodzie biograficznej niemieckiego socjologa Fritza Schützego ${ }^{3}$ i jest coraz bardziej docenianym sposobem prowadzenia badań naukowych przez historyków ${ }^{4}$. Korzystają z niej także socjologowie zajmujący się historią

1 R. Śmietanka-Kruszelnicki, Protokót przestuchania jako źródto historyczne, [w:] Wokót teczek bezpieki - zagadnienia metodologiczno-źródtoznawcze, red. F. Musiał, Kraków 2006, s. 357-366.

2 Szerzej stan badań nad historią mówioną opracowuje Izabela Lewandowska w artykule Oral history we wspótczesnej Polsce - badania, projekty, stowarzyszenia, „Wrocławski Rocznik Historii Mówionej", R. 1 (2011), s. 81-103.

3 K. Kaźmierska, Wywiad narracyjny - technika i pojęcia analityczne, [w:] M. Czyżewski, A. Piotrowski, A. Rokuszewska-Pawełek, Biografia a tożsamość narodowa, Łódź 1997, s. 35-44.

4 M. Kurkowska-Budzan, Antykomunistyczne podziemie zbrojne na Białostocczyźnie: analiza wspótczesnej symbolizacji przesztości, Kraków 2009; Oral history: the challenges of dialogue, ed. M. Kurkowska-Budzan, K. Zamorski, Amsterdam-Philadelphia 2009; D. Kałwa, Historia mówiona codzienności, [w:] Pokolenie, które gonito czas, Kraków 2010, s. 8-12; D. Kałwa, B. Klich-Kluczewska, Wojenne rozdzielenie, czyli prywatna historia II wojny światowej, [w:] Wystawa Muzeum Historii Polski: Wojenne rozstania 11.11.2009-12.01.2010, Warszawa 2009, s. 17; From mentalites to anthropological history: theory and methods, red. B. Klich-Kluczewska, D. Kałwa, Kraków 2012; B. Klich-Kluczewska, Przez dziurke od klucza. Życie prywatne w Krakowie (1945-1989), Warszawa 2005; J. Pałka, M. Venken, K.M. Zalewski, Żołnierze generała Maczka. Doświadczenie i pamięć wojny, Gdańsk-Zakrzewo 2013; W. Kudela -Świątek, Odpamiętane: o historii mówionej na przykładzie narracji kazachstańskich Polaków o represjach na tle narodowościowym i religijnym, Kraków 2013; Wspomnie- 
i pamięcią ${ }^{5}$. Nie jest moim zamiarem analizowanie teorii historii mówionej i zagłębianie się w jej niuanse, więc przypomnę jedynie jej definicję przyjętą przeze mnie w edycji źródłowej wywiadów z 2013 r., z wykorzystaniem ram przedmiotowych historii mówionej, zaproponowanych przez Piotra Filipkowskiego ${ }^{7}$.

„Historia mówiona”, a według Marty Kurkowskiej-Budzan, „historia opowiadana" ${ }^{\text {to }}$ "samoświadoma, poddana pewnej dyscyplinie rozmowa między dwiema osobami na temat niektórych aspektów (doświadczonej) przeszłości uważanych przez słuchacza i rozmówcę za historycznie istotne, prowadzona z zamiarem jej zarejestrowania. Komunikacja ta, choć przybiera postać relacji, pozostaje dialogiem - jej forma i treść zależą od pytań (a te od kontekstów, w jakich porusza się pytający), od przeświadczenia rozmówcy o tym, co jest, a co nie jest istotne. Spotkanie jest więc dynamiczną interakcją"

Ta definicja, zapewne wymagająca uzupełnienia, pozostanie w tym artykule punktem wyjścia do porównania dwóch relacji będących wynikiem spotkania historyka i prokuratora ze świadkiem. Przedmiotem mojej analizy jest zestawienie podobieństw i różnic między powstałymi w ten sposób źródłami historycznymi. W dalszej części będę starał się przybliżyć metodologię pracy historycznej prokuratorów zatrudnionych w IPN, ze szczególnym naciskiem na ich współpracę z tzw. świadkami

nia repatriantów $z$ Kazachstanu wysiedlonych w latach 3o. XX w. w głą ZSRR, red. W. Kudela-Świątek, Kraków 2007.

5 P. Filipkowski, Historia mówiona i wojna. Doświadczenie obozu koncentracyjnego w perspektywie narracji biograficznych, Wrocław 2010, s. 21-23; K. Kaźmierska, Biografia i Pamięć. Na przykładzie pokoleniowego doświadczenia zagłady, Kraków 2008; eadem, Doświadczenie wojenne Polaków a kształtowanie tożsamości etnicznej. Analiza narracji kresowych, Warszawa 1999; A. Wylęgała, Od Kreuz do Krzyża: losy niemieckich i polskich mieszkańców miasta w XX wieku, Warszawa 2009; eadem, Przesiedlenie a pamięć. Studium (nie)pamięci społecznej na przykładzie ukraińskiej Galicji i polskich „Ziem Odzyskanych”, Toruń 2014.

6 Relacje wojenne ziemian. Perspektywa dwóch pokoleń, wybór i oprac. M. Chorązki, Kraków 2013.

7 P. Filipkowski, op. cit., s. 21-23.

8 M. Kurkowska-Budzan, op. cit., s. 32.

9 Relacje wojenne ziemian..., s. 11-12. 
historii, czyli szczególnym rodzajem świadków ${ }^{10}$. W pracy pionu śledczego IPN są to zazwyczaj starsze osoby, które wielokrotnie doświadczyły przemocy i represji. W związku z tym również sposób pracy prokuratorów był i pozostaje nadal odmienny od standardów obowiązujących w prokuraturze powszechnej.

Warto podkreślić, że zaraz po zakończeniu II wojny światowej w Polsce rozpoczęła działalność Główna Komisja Badania Zbrodni Niemieckich w Polsce, której celem było „badanie i zbieranie materiałów dotyczących zbrodni niemieckich, popełnionych w latach 1939-1945 w Polsce lub poza jej granicami w stosunku do obywateli polskich lub osób narodowości polskiej”11. Dlatego tradycja śledztw, których przedmiotem były wydarzenia z najnowszej historii Polski jest dużo dłuższa, niż historii mówionej we współczesnym rozumieniu tego pojęcia. Choć jak wiadomo, pisemne relacje świadków zbierane w tym samym czasie posiadają w swych zbiorach Żydowski Instytut Historyczny w Warszawie ${ }^{12}$ i Muzeum KL Auschwitz-Birkenau ${ }^{13}$. Natomiast nagrywanie i gromadzenie relacji świadków, bliższe nowoczesnej historii mówionej zostało zapoczątkowane przez Ośrodek KARTA w latach 8o. XX w. ${ }^{14}$ Piotr Filipkowski

10 Korzystam tu z moich doświadczeń zebranych przez prawie siedem lat pracy w Instytucie Pamięci Narodowej Oddziałowej Komisji Ścigania Zbrodni przeciwko Narodowi Polskiemu w Krakowie, na stanowisku historyka - eksperta, a także opinii prokuratorów, którzy anonimowo udzielili wyjaśnień i wskazówek metodologicznych.

11 Dekret PKWN z 10 XI 1945 r. o powołaniu Głównej Komisji Badania Zbrodni Niemieckich w Polsce, Dziennik Ustaw nr 51, poz. 293, art. 3, a.

12 Relacje zgromadzone w ŻIH w Warszawie zostały zebrane przez członków żydowskich komisji historycznych utworzonych po II wojnie światowej. Materiał pozyskano w zasadzie tuż po wojnie, więc są to wspomnienia nienaznaczone dużym piętnem czasu, ale charakteryzujące się szczególnie dużą dawką emocji ze względu na bliską odległość czasową od czasów okupacji. Zob. więcej: M. Grądzka, Przerwane dzieciństwo. Losy dzieci Żydowskiego Domu Sierot przy ul. Dietla 64 w Krakowie podczas okupacji niemieckiej, Kraków 2012, s. 14-15.

13 Po II wojnie światowej pojawiła się potrzeba zachowania pamięci o okrucieństwach niemieckich popełnionych na terenie KL Auschwitz-Birkenau. W powstałym Państwowym Muzeum w Oświęcimiu od połowy lat 50. XX w. zaczęto na szeroką skalę zbieranie relacji ustnych. Nagrywane relacje były transkrybowane i archiwizowane, a następnie opracowywane do celów naukowo-badawczych. Zob. szerzej: I. Lewandowska, op. cit., s. 81-82.

14 Od końca lat 8o. XX w. Ośrodek KARTA dokumentował represje sowieckie wobec obywateli polskich na terenie województw wchłoniętych do ZSRS w 1939 r. Od kilku lat zgromadzone są one, razem z innymi, dotyczącymi walki żołnierzy podziemia 
porównując relacje przeprowadzone z tymi samymi świadkami przez pracowników Muzeum KL Auschwitz-Birkenau w latach 6o. i 70 XX w. i prowadzonymi współcześnie przez pracowników Ośrodka KARTA wykazał interesujące różnice wynikające z zastosowania różnych metod zbierania relacji ${ }^{15}$.

IPN jest instytucją, która jako spadkobierczyni przywoływanej w tym miejscu Głównej Komisji Badania Zbrodni Niemieckich, a następnie Głównej Komisji Zbrodni Hitlerowskich, prowadzi nieustannie śledztwa przeciwko zbrodniarzom lub w sprawie zbrodni popełnionych na obywatelach polskich w latach 1939-1989 ${ }^{16}$. Jednym z podstawowych założeń prowadzonych śledztw było dotarcie do żyjących świadków tych wydarzeń i pozyskanie ich zeznań jako materiałów dowodowych. Zgromadzone materiały mają obecnie przede wszystkim charakter historyczny, choć w wielu przypadkach są one na bieżąco wykorzystywane w prowadzonych dochodzeniach. W śledztwach służą nie tylko wyjaśnianiu okoliczności wydarzeń sprzed lat, ale stanowią ważne źródło historyczne dotyczące epoki.

O ile celem historyków jest samo pozyskanie relacji opisujących koleje losu świadków oraz zaobserwowane wydarzenia historyczne czy też zjawiska społeczne, celem prokuratorów jest uzyskanie informacji niezbędnych do śledztw. Przy czym obu - historykom i prokuratorom, chodzi w zasadzie o to samo: o ustalenie co się właściwie wydarzyło ${ }^{17}$.

Efektem pracy prokuratorów są także liczne protokoły przesłuchań, zbieranych od początku istnienia Głównej Komisji Badania Zbrodni

niepodległościowego, w Archiwum Historii Mówionej i udostępniane zainteresowanym w Domu Spotkań z Historią w Warszawie. Instytucja ta wykonała w ostatnich latach kilka nowych projektów oral history, dokumentując liczne wspomnienia obywateli polskich doświadczonych przez represje okupantów oraz komunistycznego aparatu represji. Zob. szerzej: I. Lewandowska, op. cit., s. 90-93; http://www.karta. org.pl (dostęp: 15 I 2015 r.).

15 P. Filipkowski, O relacjach bytych więźniów kacetów w kontekście czasu, miejsca i sytuacji ich powstania (albo o pożytkach z historii mówionej), „Wrocławski Rocznik Historii Mówionej", R. 2 (2012), s. 37-71.

16 Ustawa z 18 XII 1998 r. o Instytucie Pamięci Narodowej Komisji Ścigania Zbrodni przeciwko Narodowi Polskiemu, Dziennik Ustaw 155, poz. 1016; także: http://ipn.gov. pl/o-ipn/ustawa/ustawy (dostęp: 26 XI 2015 r.).

17 Ostatnio pracę historyka i prokuratora bardzo cennie porównał Marek Cetwiński, „Potężniejszy od Boga”. Historyk a granice naukowego poznania przeszłości, [w:] Ad. Fontes. O naturze źródta historycznego, red. S. Rosik, P. Wiszewski, Wrocław 2004, S. $17-25$. 
Niemieckich w Warszawie ${ }^{18}$, aż do czasów współczesnych, które są dzisiaj cennym źródłem historycznym.

Protokół przesłuchania świadka jest specyficzną formą wywiadu - to przede wszystkim sformalizowanie relacji świadka wydarzenia (niezależnie, czy dotyczy to przestępstwa, czy też zdarzenia losowego, takie jak wypadek komunikacyjny). Posiada charakter dokumentu urzędowego, w którym kluczowy jest jego prawno-karny charakter. Zachowanie świadka jest tu ograniczone przez zasady i reguły wyznaczane przez kodeks karny Rzeczypospolitej Polskiej, a także przez pytania osoby przesłuchującej. Świadek uprzedzony o odpowiedzialności karnej wynikającej z artykułów Kodeksu Karnego, jest zobowiązany do mówienia prawdy i niezatajania żadnych faktów ani też wydarzeń, które zapamiętał. W przeciwnym razie będzie odpowiadał za składanie fałszywych zeznań, łącznie z sankcją możliwej kary pozbawienia wolności ${ }^{19}$. Niestety, nigdy nie ma gwarancji, że składane zeznanie jest zgodne z prawdą. Wpływ na to może mieć nie tylko świadome

18 Jej działalność stanowi kontynuację prac Głównej Komisji Badania Zbrodni Niemieckich w Polsce, która powstała w 1945 r. W 1949 r. została zmieniona nazwa Komisji na Główną Komisję Badania Zbrodni Hitlerowskich w Polsce, pod którą to nazwą Główna i Okręgowe Komisje kontynuowały prace śledcze i badawcze, z przerwami i z różną intensywnością, do 1991 r. Od momentu zmiany nazwy rozpoczęło się stopniowe „wygaszanie” działalności Komisji - w tym czasie zlikwidowano poszczególne okręgowe Komisje, pozostawiając jedynie do 1953 r. krakowską Komisję oraz Główną Komisję w Warszawie, gdzie zlokalizowano centralne archiwum. Komisje reaktywowano w poszczególnych okręgach w 1965 r. i przetrwały w tym kształcie do $1999 \mathrm{r}$. W $1991 \mathrm{r}$. Komisja, która na mocy ustawy z 4 kwietnia 1991 r. (Dz. U. 91.45.195) przyjęła nazwę: Główna Komisja Badania Zbrodni przeciwko Narodowi Polskiemu - Instytut Pamięci Narodowej, rozszerzyła formalnie zarówno merytoryczny, jak i czasowy zakres działalności. Swoim zainteresowaniem objęła nie tylko zbrodnie niemieckie popełnione w czasie okupacji hitlerowskiej, lecz także zbrodnie stalinowskie oraz inne przestępstwa, które zostały zaliczone do przestępstw nieulegających przedawnieniu, popełnione na obywatelach polskich w latach 1939-1956. Zob. szerzej: R. Kotarba, Okregowa Komisja Badania Zbrodni Hitlerowskich w Krakowie 1945-1953, „Krzysztofory”, nr 17 (1990), s. 66-74; A. Kura, Martyrologia wsi polskiej wokresie II wojny światowej w świetle śledztw Instytutu Pamięci Narodowej, [w:] Zbrodnie przeszłości. Opracowania i materiaty prokuratorów IPN, t. 3, Nazizm, red. R. Ignatiew, A. Kura, Warszawa 2009, s. 26-30; http://ipn.gov.pl/o-ipn/struktura/kszpnp (dostęp: 10 IX 2014 r.).

19 Art. $233 \$ 1$ Kodeksu Karnego. 
manipulowanie przez świadka faktami historycznymi, ale również mechanizmy psychologiczne związane z działaniem pamięci autobiograficznej ${ }^{20}$.

Może się wydawać, że zasady przyjęte podczas pracy ze świadkami są uniwersalne dla prokuratorów i historyków, jednak analiza pokazuje, że obydwie metody znacznie różnią się od siebie w celach i środkach, jakie stosują. Szczególnie jest to widoczne w przypadku osób, które były przesłuchiwane przez prokuratorów IPN i nagrywane przez historyków. Na potrzeby niniejszego artykułu przedstawiony zostanie jeden przykład, Stefana Kuliga, urodzonego w 1925 r. w Obłazach Ryterskich w rodzinie chłopskiej żołnierza ZWZ-AK. W grudniu 1942 r. został on aresztowany przez nowosądeckie gestapo i po krótkim śledztwie trafił do niemieckiego obozu KL Auschwitz-Birkenau, a następnie, po ewakuacji w styczniu 1945 r., do KL Ravensbrück. Po szczęśliwym powrocie do domu w lecie 1945 r., był dwukrotnie aresztowany przez UBP, m.in. pod zarzutem przynależności do Polskiej Podziemnej Armii Niepodległościowej. Wyrokiem WSR w Krakowie w dniu 23 grudnia 1948 r. został skazany na karę pozbawienia wolności na 5 lat $^{21}$. W związku z tymi przeżyciami od 1969 r. był kilkakrotnie przesłuchiwany przez prokuratorów OKBZH w Krakowie, a następnie IPN w Krakowie ${ }^{22}$. Ponadto historycy IPN przeprowadzili z nim w 2012 r. kilkugodzinny wywiad $^{23}$. Warto zaznaczyć, że historycy spotkali się ze Stefanem Kuligiem najpóźniej i jego kondycja zdrowotna nie była już wówczas najlepsza. Obecnie jest to osoba sędziwa, która obok zwykłych dolegliwości typowych dla wieku, ma problemy z pamięcią. Często brakuje mu słów, narzeka na trudne wspomnienia, które wielokrotnie go prześladowały.

Liczba relacji świadków IPN OBEP jest kilkakrotnie mniejsza w porównaniu do liczby przesłuchanych świadków przez OKŚZpNP IPN w Krakowie.

20 T. Maruszewski, Pamięć autobiograficzna, Gdańsk 2005.

21 M. Chorązki, Sądeccy „wrogowie ludu” - między pamięcia jednostek a dokumentami UB, [w:] Masz synów w lasach Polsko... Podziemie niepodległościowe i opór społeczny na Sądecczyźnie w latach 1945-1956, red. D. Golik, Nowy Sącz 2014, s. 301-306.

22 Stefan Kulig był przesłuchiwany: 11 XI 1969 r. (S 1/74 - obecnie S 78/11/Zn, zbrodnie na terenie KL Auschwitz-Birkenau), 8 VI 1992 r. (S 6/91/UB - obecnie S 13/oo/Zk, zbrodnie funkcjonariuszy WUBP w Krakowie), 27 I 2010 r. (S 13/oo/Zk, zbrodnie funkcjonariuszy WUBP w Krakowie). Ponadto złożył dwie relacje napisane w dniach: 28 III 1992 r. i 29 IV 1993 r., obydwie dołączone do akt śledztwa S 6/91/UB, obecnie S 13/oo/ Zk.

23 Nagrania miały miejsce 2 IV 2012 r. i 2 VIII 2012 r. Składały się z dwóch dwugodzinnych relacji. Autorami nagrania byli Marcin Chorązki i Dawid Golik. 
Według ostatnich danych w zasobie relacji znajdują się 303 filmy nagrane przez pracowników krakowskiego Oddziału IPN, podczas gdy prokuratorzy IPN OKŚZpNP w Krakowie przesłuchali w trakcie 15 lat istnienia Instytutu 7821 świadków ${ }^{24}$. Materiały archiwalne związane ze Stefanem Kuligiem są na tyle ciekawe, że posłużą nam jako podstawa źródłowa do analiz i postawienia wstępnych hipotez odnośnie do tytułowego zagadnienia.

Teoria prowadzenia prokuratorskiego przesłuchania zakłada nieskrępowane, ale kontrolowane uzyskiwanie informacji na interesujące śledczego tematy. Podstawowe założenie kodeksu postępowania karnego nakłada na wezwanego świadka obowiązek stawienia się przed prokuratorem lub sędzią celem złożenia zeznań. Jedynie udokumentowana choroba zwalnia potencjalnego przesłuchiwanego od tego obowiązku, a ciężar wypełnienia powinności śledczej składa się na prokuratora, który musi przesłuchać świadka w jego miejscu zamieszkania, lub czasowego pobytu (np. w szpitalu lub innym tego typu ośrodku $)^{25}$. W przypadku relacji historycznych istotną różnicą jest dobrowolność świadka - nie ma i nie może być przymusu w składaniu takiej relacji. Jest więc to często spotkanie na wpół towarzyskie, bez obciążenia wynikającego z prawa. $\mathrm{Z}$ takim podejściem wiążą się także ważkie kwestie wynikające $\mathrm{z}$ etyki prowadzenia badań. Nikogo nie można zmusić do opowiedzenia swojej historii, nie można przed nim zatajać celu badań ani rejestracji rozmowy. Sprawy te wciąż jeszcze wymagają poważniejszej refleksji środowiska historycznego ${ }^{26}$.

W przypadku Stefana Kuliga mamy do czynienia z aktywnym udziałem w śledztwach historycznych, co wynika z dokumentów znajdujących się w posiadaniu prokuratorów i historyków. Nie stronił od kontaktów z pracownikami krakowskiej Komisji, uaktualniając posiadane w tym szczególnym

24 Zob. szerzej: Inwentarz notacji IPN OBEP w Krakowie; także: Instytut Pamięci Narodowej Oddziałowa Komisja Ścigania Zbrodni przeciwko Narodowi Polskiemu 20oo2015, Kraków 2015, s. 6.

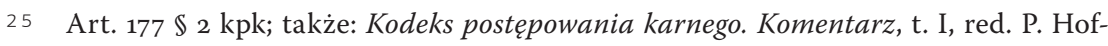
mański, Warszawa 1999, s. 670.

26 Zob. np. M. Kurkowska-Budzan, Informator, świadek, narrator - kilka wątków epistemologicznych $i$ etycznych oral history, „Wrocławski Rocznik Historii Mówionej”, R. 1 (2011), s. 28-31. 
zasobie archiwalnym ${ }^{27}$ życiorysy i zeznania. Jak wynika z akt, nigdy nie był zmuszany do zeznań (oprócz śledztw gestapo i PUBP w Nowym Sączu ${ }^{28}$ ) i z własnej woli spotykał się z prokuratorami i historykami IPN. Ostatnimi laty zeznania i nagrania wideo odbywały się w jego domu, ponieważ zdrowie nie pozwalało mu na samodzielne podróże do Krakowa ${ }^{29}$.

Według założeń teoretycznych przesłuchania świadka, „osobie przesłuchiwanej należy umożliwić swobodne wypowiedzenie się w granicach określonych celem danej czynności, a dopiero następnie można zadawać pytania zmierzające do uzupełnienia, wyjaśnienia lub kontroli wypowiedzi”30. Od samego początku proces przesłuchania przybiera charakter rozmowy będącej pod ścisłą kontrolą. Każdy przesłuchujący przed spotkaniem ze świadkiem ma już zazwyczaj wiedzę na temat wydarzeń, którą chce z nim zweryfikować, przygotowuje zatem zestaw pytań. Pierwsza część przesłuchania jest przeważnie, zgodnie $\mathrm{z}$ założeniem, swobodną wypowiedzią świadka - krótkim przybliżeniem pochodzenia oraz wspomnień z pierwszego okresu życia. Według komentarza do Kodeksu postępowania karnego: „Swobodna relacja to przede wszystkim relacja nie przerywana pytaniami i wtrąceniami ze strony organu przesłuchującego [...]. Swoboda relacji osoby przesłuchiwanej ma jednak swoje granice. Stanowi je cel danej czynności. Cele postępowania karnego [...] sprowadzają się do wykrycia sprawcy i pociągnięcia go do odpowiedzialności karnej, wyjaśnienia okoliczności sprawy, zbadania i utrwalenia dowodów"31.

Po swobodnej wypowiedzi następuje faza właściwego przedmiotowo przesłuchania, którego celem jest uzyskanie odpowiedzi na pytania przygotowane wcześniej, a także na te pojawiające się podczas rozmowy. „Pytania te mogą dotyczyć kwestii pominiętych przez osobę przesłuchiwaną

27 Zakończone śledztwa IPN OKŚZpNP w Krakowie są systematycznie przekazywane do archiwum zakładowego krakowskiego Oddziału IPN, które znajduje się w siedzibie IPN OBUiAD w Wieliczce. Akta śledztw niezakończonych i zawieszonych znajdują się w archiwum podręcznym IPN OKŚZpNP w Krakowie. Ten status posiadają akta śledztw, w których znajdują się dokumenty wytworzone przy współudziale Stefana Kuliga. Stanowią więc szczególny zasób archiwalny Oddziału IPN w Krakowie. Zasady ich udostępniania są omówione przez autora w innym miejscu niniejszego artykułu.

28 M. Chorązki, op. cit., s. 301-306.

29 Ostatnie zeznania i nagrania Stefana Kuliga odbywały się w latach 2010-2012.

30 Kodeks Postępowania Karnego..., s. 629.

31 Ibidem, s. 631-632. 
w fazie swobodnej wypowiedzi lub zmierzać do uściślenia tych kwestii poruszonych przez osobę przesłuchiwaną, które tego wymagają" ${ }^{\prime 2}$. Jest to bowiem miejsce na dopowiadanie i wyjaśnianie związków między pamięcią świadka a wiedzą prokuratora. Postawione pytania stanowią nie tylko uzupełnienie dotychczasowej jego wiedzy, lecz także samej kontroli wiarygodności świadka. Kolejność pytań, jak również ich forma pozostają w gestii śledczego. Nie mogą być jednak sugerujące odpowiedź, gdyż to prowadzi do podważenia wiarygodności zeznania ${ }^{33}$.

Prokurator zazwyczaj dba o to, by świadek w trakcie narracji nie odbiegał od meritum śledztwa, co jest istotnym ograniczeniem swobodnego toku narracji. Śledczy jest przeważnie zainteresowany wyłącznie przedmiotem swych dociekań. Nie interesują go inne wątki - zjawiska, wydarzenia lub ludzie w przeszłości związani ze świadkiem. Stara się nie dekoncentrować świadka i siebie innymi treściami jego wspomnień - w jego zainteresowaniu pozostają jedynie okoliczności zapamiętane jako związane z przedmiotem śledztwa. Nie ma w nich miejsca na poszerzanie wypowiedzi na temat życia codziennego, relacji międzyludzkich, funkcjonowania instytucji lub struktur, które świadek znał z autopsji. Tak było w każdym z protokołów przesłuchań z udziałem Stefana Kuliga. W pierwszym z 1969 r. opisywał przede wszystkim swój pobyt w KL Auschwitz-Birkenau, a zwłaszcza eksperymenty pseudomedyczne, którym został poddany ${ }^{34}$. W pozostałych dwóch zeznaniach przed prokuratorami krakowskiej Komisji dokładnie opisywał swe pobyty w areszcie PUBP w Nowym Sączu oraz WUBP w Krakowie, co było przedmiotem śledztw. W szczególności koncentrował się, zgodnie z oczekiwaniami prokuratora, na metodach śledczych funkcjonariuszy UBP, wskazując także sprawców swych cierpień: „Z tych funkcjonariuszy UB, którzy mnie przesłuchiwali to pamiętam nazwiska Stefkowski, imienia nie pamiętam, który w czasie jednego z przesłuchań powiedział do mnie «Niemcy cię nie wykończyli, to my cię wykończymy» [...] Przesłuchujący znęcali się nade mną, bili do utraty przytomności. Pięściami i nogami. Nie przestawali też, gdy po wcześniejszych uderzeniach przewracałem się na

32 Ibidem, s. 632.

33 Ibidem, s. 630, 633.

34 IPN Oddział w Krakowie, Zbrodnie na terenie KL Auschwitz-Birkenau, S 1/74, Protokół przesłuchania świadka Stefana Kuliga z 11 XI 1969 r., t. 1, k. 135-136. [W związku z prowadzonym obecnie śledztwem pod sygnaturą $S$ 78/11/Zn, numery tomów i kart mogły ulec zmianie.] 
podłogę"35. W 2010 r. uściślił w swym opowiadaniu metody śledcze UBP: „Bity byłem rękami i kopany nogami, a potem stylami od łopat. [...] Bili mnie też po piętach kijami" ${ }^{36}$. Rzadko zdarza się, że prokuratora interesują towarzyszące opowieści i przeżyciom emocje. Pozostają one w tle i często są pomijane w samych protokołach, jeśli nie dotyczą samego przedmiotu śledztwa. Choć, jak zauważył jeden z prokuratorów, podczas przesłuchania należy się elastycznie dostosować do okoliczności i możliwości świadka, nie stresując go oraz nie wymagając od niego pełnej wiedzy na temat analizowanych wydarzeń.

Sam dokument, w którym śledczy spisuje relację świadka, powstaje $\mathrm{w}$ trakcie przesłuchania. W początkowym okresie istnienia Komisji przesłuchanie odbywało się często w obecności sekretarki - protokolantki, która spisywała dyktowane przez prokuratora słowa świadka. Procedura w takim przypadku zakładała bowiem powtarzanie zdań wypowiedzianych przez świadka przez samego prokuratora, a następnie spisywanie ich przez wyznaczonego pracownika ${ }^{37}$. Rzadziej śledczy spisywał na maszynie zeznanie świadka lub też, co zdarzało się, ale nieczęsto, własnoręcznie długopisem czy piórem. Czasem taki dokument bywał przepisywany przez pracowników sekretariatu Komisji, ale zdarza się, że w zachowanych aktach znajdują się ręcznie pisane przez śledczych protokoły przesłuchań świadka. Często wynikało to z niewystarczającej liczby pracowników sekretariatu zatrudnionych w Komisji. Wytworzony dokument był odbijany przez kalkę w dodatkowych trzech egzemplarzach, co wynikało z praktycznych potrzeb Głównej Komisji Badania Zbrodni Hitlerowskich - były to egzemplarze do akt oraz do wysłania za granicę w celu powiadomienia wymiaru sprawiedliwości RFN lub Austrii o popełnieniu przestępstw przez ich obywateli. Miał to być dokument inicjujący lub wspierający czynności śledcze w celu pojmania i osądzenia sprawców zbrodni

35 IPN OKŚZpNP w Krakowie, Zbrodnie funkcjonariuszy WUBP w Krakowie, S 13/oo/ Zk, Protokół przesłuchania świadka Stefana Kuliga z 8 VI 1992 r., k. 63. Prawie identyczne zeznanie złożył w dniu 27 I 2010 r., k. 5913.

36 IPN OKŚZpNP w Krakowie, Zbrodnie funkcjonariuszy WUBP w Krakowie, S 13/oo/ Zk, Protokół przesłuchania świadka Stefana Kuliga z 27 I 2010 r., k. 5913.

37 Według procedury sądowej, w trakcie rozpraw pracownik sekretariatu ma obowiązek odnotować w protokole z rozprawy głównej każde pytanie ze strony sędziego, prokuratora lub adwokata i odpowiedź świadka lub oskarżonego. Zob. szerzej: Art. $144 \$ 1 \mathrm{kpk}$. 
sprzed lat, a strona polska dostarczała materiały dowodowe ${ }^{38}$. Obecnie ręcznie pisane protokoły przesłuchania świadka są wykonywane tylko w trakcie delegacji służbowej śledczego, a więc wówczas, gdy dokument powstaje poza biurem i następnie po powrocie prokuratora jest oddawany pracownikowi sekretariatu do przepisania.

Charakterystyczne $\mathrm{w}$ protokołach przesłuchań jest to, że zawsze ich uczestnicy są znani z imienia i nazwiska, znane są również ich funkcje, a w przypadku świadka data i miejsce urodzenia, miejsce zamieszkania. Wiadomo dokładnie, gdzie i kiedy doszło do spotkania oraz co świadek powiedział. Nie mamy zapisanego wiernego przebiegu spotkania, jak i pełnej treści rozmowy, ale wyłącznie uporządkowaną i wyselekcjonowaną przez śledczego treść wypowiedzi świadka. Zazwyczaj nie ma w tym dokumencie żadnego pytania prokuratora ani też jego komentarzy. Jedynym przypadkiem zachowania w aktach śledztwa pytań, które przygotowano do przesłuchania, jest korespondencja z innymi prokuratorami IPN z wybranych oddziałów lub z komisariatami policji (w przeszłości milicji obywatelskiej), z prośbą o przeprowadzenie przesłuchania świadka według załączonych pytań $^{39}$. Wówczas wiadomo, jakie kwestie szczególnie interesowały śledczego. Luźne wnioski i dywagacje świadka również nie są zapisywane. Dla prokuratora bezpośredni kontakt ze świadkiem historii nie jest najważniejszy, w czym metodologia jego pracy znacząco różni się od założeń historii mówionej, dla której kontakt historyka ze świadkiem pozostaje niezbędnym elementem ${ }^{40}$.

Przebieg przesłuchania, jego atmosfera i towarzyszące mu uczucia są nieznane czytelnikowi akt, choć odnotowuje się szczególnie ważne dla śledztwa zachowania świadka. W przesłuchaniu Kuliga w 2010 r. prokurator zaznaczył, że świadek $w$ trakcie opowiadania o śledztwie wspomniał: „Pamiętam jednak, że w czasie tych przesłuchań przychodził do pokoju

38 Zob. szerzej: A. Kura, Ściganie zbrodni nazistowskich a sprawa polskich dokumentów w Ludwigsburgu, [w:] Zbrodnie przeszłości..., s. 31-32; Notatka z rozmowy z Ryszardem Kotarbą, byłym dyrektorem Okręgowej Komisji Badania Zbrodni Hitlerowskich w Krakowie z 30 IX 2014 r.

39 Art. $177 \$ 2 \mathrm{kpk}$, także: art. $585 \mathrm{kpk}$.

40 Szczególnie dużo uwagi temu zagadnieniu poświęciła Wiktoria Kudela-Świątek. Zob. szerzej: W. Kudela-Świątek, Odpamiętane: o historii mówionej na przykładzie narracji kazachstańskich Polaków o represjach na tle narodowościowym i religijnym, Kraków 2013, s. 95-185. 

[podkreśl. - M.Ch.] ${ }^{41}$. Czasem prokuratorzy odnotowują wzruszenie lub inne emocje, które wyraził świadek, lecz jest to rzadkością. Co jest ważne, szanują emocje, które targają świadkiem, jeśli nie stanowią one utrudnienia dla prowadzenia czynności procesowych. Nie akceptowane jest natomiast awanturowanie się świadków lub też zbyt żywa dyskusja z prokuratorem, którego rola i wiedza niekiedy budzą reakcje świadków. Wówczas prokurator, używając argumentów wynikających z Kodeksu postępowania karnego, interweniuje, starając się przywrócić spokój. Prokurator dokonuje na bieżąco analizy zachowania świadka, wykorzystując przy tym techniki obserwacji psychologicznej. To pozwala mu oceniać, na ile świadek zachowuje się naturalnie, a kiedy i w jaki sposób okazuje zdenerwowanie. W ten sposób kontroluje również wiarygodność świadka ${ }^{42}$.

Należy zauważyć, że to prokurator na bieżąco redaguje treści wypowiedziane przez świadka. Wynika to nie tylko z rutyny i przyjętych procedur, lecz także z naturalnych trudności z wypowiadaniem się niektórych świadków, związanych z ich poziomem wykształcenia, wiekiem czy też stresem spowodowanym składaniem zeznania. Często najprostszym zabiegiem ułatwiającym sformułowanie wypowiedzi było zadawanie pytań o charakterze zamkniętym. Wówczas odpowiedzi pozytywne lub negatywne zapisywane były $w$ formie krótkich zdań, zawierających bezpośrednią odpowiedź na pytanie $\mathrm{z}$ użyciem słów pojawiających się $\mathrm{w}$ nim samym. Ta metoda pracy pozostaje niezmienna od lat. Czasem odbywało się to w towarzystwie innych pracowników Komisji. Obecnie prokuratorzy IPN prowadzą przesłuchanie bez udziału osób trzecich, również innych pracowników IPN, zapisując wybrane zdania i treści wypowiedziane przez świadka w komputerze. Nigdy nie spotkałem się z inną formą rejestracji przesłuchania świadka - ani na dyktafonie, ani też za pomocą kamery, choć dopuszczana jest taka możliwość ${ }^{43}$. Przesłuchanie świadka przybiera charakter poufny lub co najmniej dyskretny.

41 IPN Oddział w Krakowie, Zbrodnie funkcjonariuszy WUBP w Krakowie, S 13/oo/ Zk, Protokół przesłuchania świadka Stefana Kuliga z 27 I 2010 r., k. 5914.

42 B. Bielski, Konfabulacje a ocena zeznań świadka w procesie karnym, „Prokuratura i Prawo", czerwiec 2001, s. 86-95.

43 Art. $147 \$ 1$ kpk. 
Zawsze, niezależnie od okresu historycznego, każdy protokół po odczytaniu - na głos przez pracownika Komisji lub po cichu przez samego świadka - i po wniesieniu przez niego ewentualnych sprostowań lub uwag był podpisywany. Ma to charakter swoistej autoryzacji relacji przed prokuratorem i zgody na wykorzystanie do celów procesowych. Obecnie ze względu na pracę prokuratora z pomocą komputera, poprawki i uwagi przesłuchiwanego nanosi się na bieżąco podczas odczytywania zapisanego protokołu przesłuchania. Po zaakceptowaniu treści przez świadka, podpisuje on przygotowany protokó $1^{44}$. Po dopełnieniu tych procedur protokół staje się oficjalnym materiałem śledczym, na podstawie którego prokurator może wszcząć śledztwo lub postawić zarzuty. Warto dodać, że także w przypadku historii mówionej świadek podpisuje oświadczenie, w którym wyraża zgodę na wykorzystanie relacji przez badacza w odpowiednim zakresie, ma także możliwość zastrzeżenia dla siebie autoryzacji tekstu przed jego upublicznieniem.

Przystępując do rozmowy ze świadkiem historii, historyk, niezależnie od posiadanej wiedzy, powinien przyjąć zasadę, że to świadek jest ekspertem od swojej narracji i życiorysu. Jest to przeciwieństwo sytuacji śledczej, kiedy to nadrzędną funkcję z założenia pełni prokurator, choć nie musi korygować wypowiedzi świadka, szczególnie w kwestiach nieistotnych dla śledztwa. W przypadku wywiadu autobiograficznego, który jest jednym z najbardziej popularnych wśród polskich badaczy oral history, świadek samodzielnie oprowadza historyka po swoich wspomnieniach, czując komfort niezależności wobec słuchacza. Jego wypowiedź podąża zazwyczaj w wybranych kierunkach, bez ograniczeń, często w sferach intymności i emocji ${ }^{45}$. Tego zdecydowanie brakuje świadkowi podczas przesłuchania przed organami ścigania. Pytania ze strony historyka są jedynie uzupełniającymi całość relacji, choć czasem zdają się nadawać właściwy przebieg wywiadowi.

Inaczej wygląda sytuacja, gdy prowadzony wywiad ma charakter strukturalny i odbywa się według wypracowanego przez historyka kwestionariusza pytań. Wówczas spotkanie przybiera charakter wywiadu tematycznego, koncentrującego się wokół jednego zagadnienia lub kompleksu zagadnień. Nie zmienia to faktu, że świadek ma swobodę narracji w ramach

$44 \quad$ Art. $151 \$ 1$ kpk.

45 S. Kvale, Prowadzenie wywiadów, Warszawa 2010, s. 53-54, 125-126, 128-129. 
narzuconych przez historyka tematów, a późniejsze postępowanie z nagraniem nie powinno się niczym różnić od typowych procedur postępowania $\mathrm{z}$ dokumentacją wywiadu ${ }^{46}$.

Rzeczą charakterystyczną dla obydwóch świadectw jest język źródła. W przypadku protokołów przesłuchania świadka język jest pochodną nie tylko pochodzenia czy też wykształcenia świadka, ale przede wszystkim stylu językowego prokuratora oraz ram wytyczanych przez Kodeks postępowania karnego. Inaczej wygląda sytuacja w nagrywanym wywiadzie. Wydaje się, że transkrypcja odzwierciedla nie tylko sposób wyrażania się i słownictwo świadka, lecz także stara się oddać przebieg wywiadu, emocje świadka, jak również - jeśli jest aktywny - osobowość historyka. W ten sposób otrzymujemy nie tylko pełny zapis spotkania ze świadkiem, ale przede wszystkim uzupełnienie nagrania, które w tym wypadku jest najważniejszym elementem wywiadu. Język pozostaje niezmieniony - w sposób dosłowny jest zapisywany w trakcie transkrypcji, choć jak zauważa Wiktoria Kudela-Świątek, transkrypcja nie oddaje całego charakteru wywiadu. Zapis na papierze pozostaje biernym odtworzeniem słów świadka, bez oddania emocji, jego charakteru czy też okoliczności wywiadu. Tylko historyk prowadzący wywiad potrafi właściwie zinterpretować zapisane słowa, mając w pamięci także zachowanie świadka ${ }^{47}$. Jest to doskonale widoczne na przykładzie świadectw Stefana Kuliga, którego zdenerwowanie sytuacją wywiadu jest dużo bardziej widoczne, niż w przypadku spotkania z prokuratorem. Nie kryje on swojego zakłopotania, podkreślając swoją trudną sytuację: „Kiedy jeszcze... miałem dobrą pamięć i więcej mnie interesowało, tzn. interesowało mnie tylko, że ja za dużo, za dużo... myślę o tym to ja potem nie mam, nie mam... ciężkie mam noce..." ${ }^{\text {. }}$. Nawet jeśli był tak zdenerwowany przed przesłuchaniem, prokurator tego nie zaprotokołował i przeszedł do przygotowanych pytań.

Ważnym elementem w obydwu metodach jest czas trwania spotkania. Wprawdzie Kodeks postępowania karnego i komentarze do niego nie określają ściśle długości przesłuchania, ale rzadko się zdarza, by to prokurator o tym nie decydował. To on je inicjuje, on kontroluje czas, odnotowując go w dokumentach, i on decyduje o tym, kiedy oraz w jaki sposób zostanie

46 Ibidem, s. 54-55, 124-125.

47 Zob. szerzej: W. Kudela-Świątek, op. cit., s. 95-108.

48 Notacja IPN OBEP w Krakowie ze Stefanem Kuligiem z 2 VIII 2012 r., transkrypcja, S. 1. 
ono zakończone. Zazwyczaj nie trwa ono długo - najczęściej nie więcej, niż dwie godziny. W przypadku historii mówionej doświadczenie naukowców jest różne. Najczęściej wywiad nie trwa tak krótko, zdarzają się wywiady ciągnące się przez kilka wielogodzinnych spotkań.

Ciekawym zagadnieniem są różnice $\mathrm{w}$ treści relacji nagrywanych przed i po $1989 \mathrm{r}$. W pierwszym okresie nie tylko nie ujawniano informacji dotyczących AK czy też udziału w antykomunistycznym podziemiu zbrojnym, ale posługiwano się również, najprawdopodobniej z inicjatywy prokuratorów, językiem propagandy komunistycznej, choć w tym przypadku mógł to być język zapisującego relację, a nie mówiącego. Według Ryszarda Kotarby oraz Antoniego Kury, przyczyny pomijania w zeznaniach świadków informacji o ich aktywności w ZWZ-AK mają również inne podłoże. Znaczenie miała tu przypuszczalnie wykładnia stosowana przez wymiar sprawiedliwości RFN odnośnie do represji władz okupacyjnych wobec żołnierzy polskiego podziemia. Otóż akty te uznawano za usprawiedliwione $\mathrm{w}$ świetle prawa międzynarodowego oraz niemieckich norm prawnych narzuconych na okupowanych ziemiach polskich, gdyż według niemieckich prawników były zgodne m.in. z Konwencją Haską z 1907 r. Dlatego jedynie przemoc wobec osób cywilnych, nie zaangażowanych w działalność partyzancką dawała potencjalną możliwość pociągnięcia sprawców do odpowiedzialności. Stąd wniosek, że prokuratorzy Komisji nie zapisywali informacji o udziale swych świadków w działalności konspiracyjnej, podkreślając $\mathrm{w}$ ten sposób ich status jako ofiar niemieckiego terroru ${ }^{49}$. W protokole z pierwszego przesłuchania Stefana Kuliga nie znajdujemy informacji o jego udziale w strukturach ZWZ-AK. Jest jedynie lakoniczna wzmianka: „W dniu 24 grudnia 1942 r. w Rytrze zostałem aresztowany przez gestapo za pracę konspiracyjną, albowiem zajmowałem się przerzutem kurierów podziemia przez Słowację na Węgry" ${ }^{50}$. Dopiero przełom $1989 \mathrm{r}$. i utworzenie obecnego IPN doprowadziły do zmiany strategii przesłuchań, a także do umożliwienia składania zeznań obciążających funkcjonariuszy komunistycznego aparatu represji. Kulig po latach opowiadał, że: „Po wybuchu wojny w październiku 1939 r. wstąpiłem do

49 A. Kura, Ściganie zbrodni..., s. 37-39; Notatka z rozmowy z Ryszardem Kotarbą, byłym dyrektorem Okręgowej Komisji Badania Zbrodni Hitlerowskich w Krakowie $\mathrm{z} 30$ IX $2014 \mathrm{r}$.

50 IPN Oddział w Krakowie, Zbrodnie na terenie KL Auschwitz-Birkenau, S 1/74, Protokół przesłuchania świadka Stefana Kuliga z 11 XI 1969 r., t. 1, k. 135. 
ruchu oporu ZWZ, a następnie AK. Nosiłem pseudonim «Gorol». Moim zadaniem jako łącznika było przeprowadzanie na szlaku kurierskim oficerów polskich do punktów na Słowacji. Pełniłem też funkcję kolportera prasy konspiracyjnej AK" ${ }^{\prime \prime}$.

Obecnie zarówno $\mathrm{w}$ ramach protokołów przesłuchań przed prokuratorami IPN, jak i przed kamerami lub dyktafonami historyków wielu spośród rozmówców śmiało opowiada o swej przeszłości, ujawniając ukrywane wcześniej fakty z działalności politycznej czy też konspiracyjnej. Oczywiście istnieją tematy niechętnie poruszane, albo wręcz pomijane, w szczególności te dotykające problemów etycznych lub dotyczących sfer prywatności. Świadkowie poruszają przeróżne wątki, często traktując relację jako ostatnią szansę na powiedzenie prawdy i na swoistą terapię. To wówczas dochodzi do wyznań z najbardziej skrywanych wydarzeń, traumatycznych przeżyć. W przypadku Stefana Kuliga takim trudnym przeżyciem był opis gwałtu żołnierzy sowieckich na warszawiance, więźniarce KL Ravensbrück. Nikomu tej historii wcześniej nie opowiadał, ale podczas tej rozmowy zwierzył się z tego jednego z najbardziej przykrych wspomnień ${ }^{52}$. Podczas zeznania przed prokuratorem takie chwile są rzadsze, a prokurator nawet jeśli współuczestniczy w tych przeżyciach, zachowując zrozumienie dla uczuć świadka, nie odnotowuje takich szczegółów w protokole. Momenty "oczyszczenia” świadka stanowią pewną intymną część przesłuchania, która jest rzadko ujawniana nawet w prywatnych rozmowach prokuratorów. Jest to zasadnicza odmienność od relacji oral history, która jest rejestrowana z myślą o publicznym wykorzystaniu. Jedynie zakaz ze strony świadka (werbalny lub pisemny) stanowi granicę działań historyka. Podobnie jak wszelkie uwagi poczynione przez świadka podczas autoryzacji transkrypcji relacji, jeżeli takową sobie zastrzeże. Ma to zresztą istotny wpływ na treść relacji, gdyż często świadkowie dokonują wówczas gruntownej przebudowy narracji, starając się wprowadzić język literacki. Szczególnie jest to widoczne w przypadku osób wykształconych. Uważają, że w ten sposób nadają spisanej relacji charakter właściwy dla

51 IPN Oddział w Krakowie, Zbrodnie funkcjonariuszy WUBP w Krakowie, S 13/oo/ Zk, Protokół przesłuchania świadka Stefana Kuliga z 8 VI 1992 r., k. 62. Podobne zeznanie złożył w dniu 27 I 2010 r., zob. Zbrodnie funkcjonariuszy WUBP w Krakowie, S 13/oo/Zk, Protokół przesłuchania świadka Stefana Kuliga z 27 I 2010 r., [brak numeru kart].

52 Notacja IPN OBEP w Krakowie ze Stefanem Kuligiem z 2 VIII 2012 r., transkrypcja, S. $1-2$. 
ich statusu społecznego - unikają kompromitacji w oczach historyków. Warto zaznaczyć, że w trakcie autoryzacji pojawia się także zjawisko autocenzury, dlatego trwa dyskusja, zarówno wśród historyków, jak i dziennikarzy, jak bardzo świadek powinien mieć możliwość ingerowania w tekst transkrypcji53.

Fundamentalną różnicą między źródłem wytworzonym przez historyka i prokuratora jest jego forma, gdyż jak zostało wyżej wskazane, prokuratorzy, w przeciwieństwie do historyków, w zasadzie nie korzystają z rejestracji relacji w postaci nagrania audio lub audio-wideo. Rejestracja dźwiękowa i obrazowa jest dodatkowym atutem w stosunku do zapisu pisemnego tych źródeł, gdyż pozwala na analizę emocji i uczuć uzewnętrznianych w trakcie rozmowy. W przypadku protokołów przesłuchań zazwyczaj nie dowiemy się nic na temat samego zachowania, mimiki czy też emocji towarzyszących świadkowi.

Nieznajomość wzajemnych warsztatów pracy historyka i prokuratora powoduje nieporozumienia i rozczarowania. W protokołach przesłuchań, które często są jedynymi źródłami, brakuje poszerzonych informacji biograficznych. Prokuratorzy nie znający kontekstu historycznego, nie potrafią zadać istotnych pytań z punktu widzenia analizowanych wydarzeń, często nie dostrzegają także wartości relacji nagrywanych przez historyków. W związku z tym ważnym postulatem jest moim zdaniem większa wzajemna współpraca historyków z prokuratorami. Szczególnie w kwestii dostępu do materiałów i lepszego zrozumienia źródeł. Dla badaczy niezbędne jest korzystanie z materiałów Komisji Ścigania Zbrodni przeciwko Narodowi Polskiemu. Choć trzeba pamiętać o ograniczeniach wynikających z Kodeksu postępowania karnego dotyczących tzw. śledztw w biegu, które nie zakończyły się prawomocnymi decyzjami wymiaru sprawiedliwości. Natomiast dla prokuratorów ważny jest dostęp do wiedzy historycznej oraz do materiałów archiwalnych. Jednak należy mieć świadomość, że dokumenty śledztw będących „na biegu” nie mogą być udostępnione nikomu, oprócz stron bezpośrednio zaangażowanych (świadków, podejrzanych lub ich pełnomocników). Jest to realizacja tzw. zasady tajności akt postępowania przygotowawczego. Dlatego do analizy pozostają akta śledztw tylko tych ostatecznie zakończonych prawomocną decyzją sądu lub prokuratora ${ }^{54}$.

53 Zob. np. I. Borkowski, Wspótczesny prasowy wywiad dziennikarski: techniki prowadzenia, opracowanie, publikacja, „Wrocławski Rocznik Historii Mówionej”, R. 1 (2011), s. 76-77.

54 Art. $156 \mathbb{1}, 5 \mathrm{kpk}$. 
Every questioning of a witness by a prosecutor is of a legal and formal nature. Its aim is to determine "what really happened". A historian, if interested not only in reconstruction of the course of events, strives to get to know the world of the witness he or she is interviewing. These aims determine the methods, but do not exclude learning from each other's experience, as well as results of investigations, inquiries and research. The same person can be the subject of interest for a narrative; a prosecutor and a historian can complement each other in their findings. This article represents a contribution to the discussion on the differences in methodology in the work of historians and prosecutors, as well as the importance of interviews with witnesses for the research on contemporary history.
Marcin Chorązki

Witness, questioning protocol and witness account as sources of studies on contemporary history. Similarities and differences in the work of an IPN (the Institute of National Remembrance) prosecutor and a historian 